(the last sometimes becoming marbles) are not altered Jurassic rocks, but are much older.

2. "Notes on some Trachytes, Metamorphosed Tuffs, and other Rocks of Igneous Origin, on the Western Flank of Dartmoor." By Lieutenant-General C. A. McMahon, F.G.S.

In this paper the author notices the occurrence of felsite and trachyte at Sourton Tor; of rhyolite and of aluminous serpentine at Was Tor; and of a dolerite at Brent Tor in the exact situation indicated by Mr. Rutley as the probable position of the throat of the Blent Tor volcano.

The author describes extensive beds of tuffs at Sourton Tor and Meldon, the matrix of which has been converted, by contact-metamorphism, into what closely resembles the base of a rhyolite, and which, in extreme cases. exhibits fluxion-structure, or a structure closely resembling it. The fragments included in this base are so numerous that six or seven different species of lavas may be seen in a single slide; this fact, and a consideration of the extensive area over which these beds extend, lead the author to believe that these beds are metamorphosed tuffs and not tufaceons lavas.

He then describes some beds on the flank of Cock's Tor, which give evidence on their weathered surface of an original laminated structure by exhibiting a corded appearance like corduroy cloth. These beds are composed of colourless augite, set. in a base which in ordinary light looks like a structureless glass, but which between crossed nicols is seen to be an obscurely crystalline felspar.

The author compares these rocks with that portion of the Lizard bornblende schists for which a tufaceous origin was proposed by De la Beche and other writers, including Prof. Bonney and himself. He shows that the Lizard schists and the Cock's Tor rocks agree in specific gravity and in some other characteristics; and be concludes that at Cock's Tor the first stage in the conversion by contact-action of beds of fine volcanic ash into hornblende-schist had been completed, and the final stage, due to aqueous agencies, had just begun.

The paper concludes with some remarks on the relationship of the epidiorites to the rocks of volcanic origin.

\title{
CORRESPONDEINEE.
}

\section{GEOLOGICAL DIFFICULTIES IN THE LEPONTINE ALPS.}

Sir,--Dr. Stapff's interesting paper in your April Number seems to call for a few words of explanation from myself. As regards the Altkirche marble, the problem which it presents has been discussed in a paper recently read before the Geological Society, to which I may refer. Here, it may suffice to say, that I have not denied that certain limestones near Altkirche may contain fragments of organisms, but doubt the occurrence of these in the true marble, i.e. we have here not only to distinguish imitative from truly organic markings (in which photographic evidence often is not sufficient), but also to settle the age of the rock in which the latter occur. 
As for the Piora schists, I am sorry to have misunderstood Dr. Stapff, but think he would have done better to refer to my letter as published in the Geologicar Magazine (1892, p. 90) instead of to an abstract of it, necessarily condensed. He will find my words to be "If I am right in understanding Dr. Stapff to assign the Piora schists to the Carboniferous system," etc. 'The fact is that I had great difficulty in coming to a conclusion both as to the exact position of the divisions which he had drawn in his published sections and paper, and as to how much was covered by the terms which he employed. The terminology of petrologists at present is rather unsettled, so that we do not seldom find difficulties of this kind arising in regard to details. But if the Piora schists are part of a series extending "from the Carboniferous to the Jurassic age," I fear that I must leave the remainder of the sentence partly quoted at the top of page 160 otherwise unaltered.

My remark as to the inadequacy of photographs to decide whether organisms occurred in the Altkirche marble applies equally to the "sand grains" in the Guspis gneiss. That a gneiss may be of sedimentary origin I do not deny, but I doubt whether it would be possible to recognize with certainty the original clastic grains, unless they had been so large as to make this term inappropriate. For instance, I have examined many quartz-schists, in which I suspected certain grains to indicate the position of original constituents, but have met with only one case which I felt would satisfy a sceptic (discovered by Mr. J. Eccles last summer), and here they were pebbles rather than grains. But $I$ have seen many cases where a structure, due to the crushing of a crystalline rock, wonderfully simulates that of an ordinary clastic rock, so, as I have been more than once led into error in this matter, the proverb holds good, "once bit, twice shy."

T. G. BONNEY.

\section{DR. ALEX. BROWN ON SOLENOPORA.}

Sir,-In Dr. Brown's article on the structure of Solenopora there is a slight error in the horizon given for the Yorkshire specimens which should be corrected, especially as the rock in question was for some time considered to be the equivalent of the Great Oolite. The Malton specimens are obtained from the Corallian, and they are also very abundant throughout the Ayton-Brompton Coral Rag.

Geological Survex,

C. Fox Strangways.

Leicester.

\section{MR. WATTS'S PAPER ON THE TARDREE PERLITE.}

SrR,-On thinking over the subject of Mr. Watts's interesting paper read before the Geological Society on March 21st last, in which he endeavoured to prove - by means of very beautifu] magnified sections of the Tardree trachyte-that the perlitic structure is sometimes continued from the glassy magma into the enclosed crystals of quartz, it seems to me that the essentially distinct molecular strueture of the two mineral substances was nof sufficiently taken into account, and that it is only on a recognition 